\title{
TEMA SVEUČILIŠTA U CRNIM BILJEŽNICAMA MARTINA HEIDEGGERA
}

\author{
Saša Radojčić \\ Teorijski odsek, Fakultet likovnih umetnosti, \\ Univerzitet umetnosti u Beogradu, Srbija \\ sasa.radojcic@gmail.com
}

Bilješke koje je Martin Heidegger unosio u takozvane »crne bilježnice" potakle su, netom nakon objavljivanja, intenzivne diskusije, osobito oko pitanja antisemitizma i nacionalsocijalizma. Je li se Heideggerova osobna naklonost ka ovim ideologijama odrazila i na njegovo filozofsko djelo? U ovom ogledu razmatra se jedna, s ovim pitanjima povezana, važna tema $u$ Crnim bilježnicama - tema sveučilišta. Ona postaje frekventnija u tri navrata, obilježena značajnim događajima u Heideggerovoj profesionalnoj biografiji: preuzimanjem funkcije rektora sveučilišta u Freiburgu (1933.), napuštanjem te funkcije (1934.) te isključenjem iz nastave u sklopu poratne denacifikacije Njemačke (1945.). Pokazuje se da shvaćanje sveučilišta u Crnim bilježnicama odgovara idejama predočenim u Heideggerovu rektorskom govoru, kao i da to shvaćanje nije jednako nacionalsocijalističkom, već izražava filozofovo »narodnjačko« misaono usmjerenje. Iako posjeduje neke elemente vokabulara koji su bili prisutni u nacističkoj propagandi, Heidegger svoje stavove o stvarnosti i budućnosti sveučilišta integrira s drugim svojim idejama - kritikom svođenja znanja na tehničke aspekte, kritikom izoliranja znanosti u samostalna područja i uopće kritikom zapadnjačkog mišljenja.

Ključne riječi: Martin Heidegger, sveučilište, nacionalsocijalizam, znanost, kritika tehnike

Filozofima vjerojatno nije neophodno objašnjavati što su Heideggerove Crne bilježnice i u čemu je njihov značaj. Ali imajući u vidu multidisciplinarni karakter publikacije kojoj je ovaj ogled namijenjen, 
u kratkim ću crtama objasniti o kakvom djelu je riječ. Njemački filozof Martin Heidegger, jedan od najutjecajnijih mislitelja dvadesetog stoljeća, zapisivao je, počev od tridesetih pa do sedamdesetih godina, raznorodne misli u bilježnice s omotnicom crne boje, i ta je okolnost odredila njihov naslov. Sačuvane su 34 takve bilježnice, a poznato je da je postojala još jedna (prva u nizu), koju je vjerojatno uništio sam autor. Sačuvani zapisi počinju s 1931. godinom. Do sada je objavljeno šest (od planiranih devet) tomova Crnih bilježnica u okviru Heideggerovih Sabranih djela, i to: knj. 94 (1931-1938), 2014.; knj. 95 (1938/1939), 2014.; knj. 96 (1939-1941), 2014.; knj. 97 (1942-1948), 2015.; knj. 98 (1948/49-1951), 2018.; kao i knj. 99 (1947-1950), 2019., koja sadrži zapise iz zasebnog, usporedo nastalog niza od četiri bilježnice tematski okrenute problematici slike svijeta, jednog važnog motiva filozofova ukupnog opusa. Značaj Crnih bilježnica je u prvome redu u tome što pružaju mogućnost za proširivanje konteksta istraživanja Heideggerove filozofije, kao i biografije, dajući nam prisniji uvid u postupanje i sadržaje njegovog živog mišljenja.

Objavljivanje Crnih bilježnica pobudilo je globalnu pozornost u onim svojim momentima koji se tiču Heideggerova odnosa prema nacionalsocijalizmu i antisemitizmu - i to ne samo na razini čisto biografskih relacija nego i na razini njegova filozofskog djela. Ako je Martin Heidegger kao osoba potpao pod ideologije nacizma i antisemitizma (što, moram dometnuti, i nakon svih interpretacija koje to odlučno tvrde ostaje pitanje na koje treba dati jedan balansirani odgovor), što je s njegovom filozofijom? Je li i ona sama kontaminirana ovim ideologijama? Ovo pitanje je od velikoga značaja. Jer, imamo li na umu Heideggerov iznimno veliki utjecaj kako u predratnom tako i u poratnom razdoblju ne samo na njemačkom govornom području, to bi pogodilo i dobar dio suvremene europske filozofije, koja bi morala preispitati svoje nasljeđe u onoj mjeri u kojoj ga profilira mislitelj iz Schwarzwalda. Diskusija (Serafin 2015; Puzić i Pégny 2016) koja se razvila i široko razgranala ubrzo po objavljivanju Crnih bilježnica imala je i određene praktične posljedice, što ni u kojem pogledu nije uobičajeno za filozofske polemike. Predsjednik Heideggerova društva profesor Günther Figal, koji je na sveučilištu u Freiburgu držao istu onu katedru za fenomenologiju i hermeneutiku kao nekoć Heidegger, dao je opoziv koji je obrazložio time da je bio šokiran stupnjem antisemitizma sadržanom u Crnim 
bilježnicama. Potom je uprava freiburškog sveučilišta donijela odluku da nakon umirovljenja profesora Figala više ne popunjava njegovu katedru, već da ustanovi novu, na nižoj poziciji - za logiku i analitičku filozofiju jezika. Stručna filozofska javnost na to je reagirala jednom internacionalnom peticijom s oko tri tisuće potpisnika, a sveučilišni uglednici odricali su vezu između ove, navodno još ranije (2013) planirane odluke i objavljivanja Heideggerovih bilježnica iz ostavštine. Bez obzira na to je li tu zbilja riječ o pukoj koincidenciji, već sama ideja o ukidanju jedne i otvaranju druge katedre jasno ukazuje na dugoročne trendove u razvitku sveučilišne nastave filozofije i ostavlja utisak o značajnoj promjeni prioriteta u korist analitičke, a na štetu tzv. »kontinentalne« filozofije.

Ali Heideggerove zabilješke ne sadrže samo antisemitske i nacističke ideje; mjesta koja se mogu razumjeti kao izražavanje antisemitskih stavova, na oko 1700 strana koliko sadrže knjige 94-97 Sabranih djela, ima svega 13, i obuhvaćaju ne više od oko dvije i pol stranice teksta, navodi se u jednoj obrani Heideggera (von Herrmann 2016, 91; usp. također Grondin, 2016; von Herrmann i Alfieri, 2017). Zapravo, tematski krug koji zahvaćaju Crne bilježnice iznimno je širok. Spomenut ću samo neka od frekventnijih pitanja: metafizika, zasnivanje i karakter mišljenja povijesti bića (seinsgeschichtliche Denken), istina bića, događaj (Ereignis) kao način samootkrivanja ove istine, novi početak, sudbina Zapada i zapadnjačkog mišljenja, Nijemci i njemstvo, znanost, sveučilište, kultura, umjetnost, pjesništvo i drugo. U temi sveučilišta, koja je predmet ovog ogleda, prelamaju se i neke druge spomenute teme. Uvid u Heideggerovo mišljenje o sveučilištu, njegovoj ulozi u društvu i potrebi da doživi korjenitu preobrazbu i iznova se utemelji (samo-odredi) dobiva na aktualnosti danas kada se na globalnoj razini preispituju potrebe i ciljevi znanja i obrazovanja, ocjenjuju učinci obrazovnih reformi započetih na samom početku ovoga stoljeća pod lozinkom »društva znanja« i sve određenije traže neki drugačiji modeli obrazovnih institucija i politika.

Prisustvo teme sveučilišta u Crnim bilježnicama upadljivo je veće u razdobljima kada dolazi do značajnih pomaka u Heideggerovoj profesionalnoj karijeri, najprije 1933-1934. kada je nepunih godinu dana rektor freiburškog sveučilišta, i potom od kraja 1945. kada mu je, u sklopu denacifikacije Njemačke, bilo zabranjeno držati nastavu. Zato 
su fragmenti sa sveučilištem kao temom najfrekventniji u 94. i 97. knjizi Sabranih djela; s druge strane, u 96. knjizi nalaze se svega četiri mjesta na kojima se uopće i spominje riječ 'sveučilište', a u 98. knjizi - niti jedno.

Heideggerovo mišljenje o sveučilištu bilo je poznato i prije objavljivanja Crnih bilježnica. Njime dominira ocjena da je, u dosadašnjem obliku, ustrojeno prema humboldtovskom idealu zajednice podučavanja i istraživanja s autonomijom u odnosu prema političkoj sferi, sveučilište došlo do konca svoga razvitka te da tu više ne pomaže nikakva reforma, nego je neophodna obnova iz temelja. On pri tome govori o njemačkom, a ne sveučilištu kao takvom, što je potrebno imati na umu kada želimo generalizirati njegove ocjene. S jedne strane, cjelokupna Heideggerova misao obilježena je tonom narodnjačke ideologije i zavičajnosti te je on privrženiji lokalnim nego općeljudskim vrijednostima. S druge strane, sveučilište je stara njemačka filozofska tema koja je zaokupljala čitav niz mislitelja, počevši s Kantom i njegovim Sporom fakulteta, preko Fichtea i Schellinga, Schopenhauera i Nietzschea, Weberovog spisa Znanost kao poziv, do Jaspersa i njegove Ideje sveučilišta, a u najnovije vrijeme Liessmannove Teorije neobrazovanosti. Tom nizu imena Heidegger se pridružuje rektorskim govorom izloženim 27. svibnja 1933. pod naslovom Samopotvrđivanje njemačkog sveučilišta (GA 16, 107-117). ${ }^{1}$

Koje su osnovne ideje toga spisa? One dolaze iz istog registra kao i Heideggerova kritika metafizike, kritika tehničko-spravljajuće znanosti i, uopće, kritika modernosti, Zapada i zapadnjačkog mišljenja čiji je osnovni grijeh, iz čega proistječu i svi drugi nedostaci - zaborav pitanja o biću. Utoliko su Heideggerovi stavovi o sveučilištu suglasni s osnovnim stavovima njegove fenomenološko-egzistencijalne ontologije.

Ulogu rektora on shvaća kao »duhovno vodstvo tom visokom školom« (GA 16, 107), a njen bitni karakter kao samoupravu (autonomiju; Selbstverwaltung) koja se može postići jedino snagom samopotvrđivanja (Selbsbehauptung), a ovo je opet zajednička volja nastavnika i studenata za njenu bit. Prema Heideggeru, bît (njemačkog) sveučilišta je da je on visoka škola »koja iz znanosti i kroz znanost obrazuje i odgaja

${ }^{1}$ Heideggerova djela citiram prema Gesamtausgabe, kratica GA, uz broj knjige i strane. Puna bibliografska notica nalazi se u spisku literature. 
vođe i čuvare sudbine njemačkoga naroda« (GA 16, 108) u njegovoj državi. Izbor vokabulara ovdje je odista indikativan. Rektor je vođa sveučilišta u jakom smislu te riječi (Führer, a ne, primjerice, Leiter, koji je vođa u smislu onoga tko upravlja). Teško je reći je li u izboru riječi kod Heideggera određenu ulogu igrao refleks na njenu uporabu u ondašnjem govoru javnosti u Njemačkoj, gdje se vezivao za jednu ličnost - Hitlera. Kako se načelo vodstva može pomiriti sa samoupravom kao bitnim karakterom sveučilišta? Nije li vodstvo suprotno ideji samouprave? Heidegger unaprijed otklanja prigovor u ovom smislu tvrdeći da njemački studenti, koji su »na maršu«, traže takve vođe preko kojih će moći na utemeljen način razjasniti i ostvariti vlastita opredjeljenja (GA 16, 112). ${ }^{2}$ Vođa se ne postaje prisilom, nego prihvaćanjem od strane onih koji ga slijede. Prihvaćanje vođe samo je jedan od aspekata zakona koji studenti postavljaju samima sebi (što je smisao samouprave i, po Heideggeru, najveći stupanj slobode).

Iz ovog zakona (slobode) izvode se tri obveze studenata, odnosno tri službe, koje su podjednako nužne i istoga ranga: radna služba ( $A r$ beitdienst), vojna služba (Wehrdienst) i služba znanja (Wissendienst). Očito je ovdje Heideggerov dalji uzor Platonova misao o staležima u idealnoj državi i njihovim specifičnim funkcijama. Sve tri službe upućuju na usku povezanost sveučilišta, naroda i države. Ako su prve dvije službe po svome smislu manje-više jasne, kod treće bi trebalo precizirati da ona ne odgovara onom čestom shvaćanju o radu na sveučilištu kao »pozivu« ili »profesiji $\ll$.

»Znanje ne stoji u službi poziva, već obratno: pozivi uobličuju i upravljaju onim najvišim i suštinskim znanjem naroda o svom čitavom postojanju. (...) Upitnost bića uopće prisiljava narod na rad i borbu, i to u njegovoj državi, kojoj pozivi pripadaju.« (GA 16, 114)

Određenje uvjeta pod kojima znanost može danas opstati shvaća se u obnovi moći početka duhovno-povijesnog postojanja u javljanju grčke filozofije. Potreban je sada novi početak, jer se snaga onog prvobitnog potrošila. Svaka znanost je u svome početku - filozofija. Taj odnos se suviše brzo povezuje s uzornošću »teorijskog« stava, čistog

2 Usp. također jedno mjesto iz Crnih bilježnica gdje među uvjetima neophodnim za mogućnost vodstva stoji: »da je to vodstvo razvijeno iz vlastitog zakona, i nije puko podražavanje drugih odnosa vodstva« (GA 94, 126). 
promatranja koje nema drugoga cilja osim sebe samog, dok se praksa razumije kao podređena teoriji. Nasuprot tome, Heidegger smatra da je za Grke »sama teorija najviše ostvarenje prave prakse«, a znanost ne kulturno dobro, već »određujuće središte čitavog narodno-državnog postojanja« (GA 16, 110). Po ovim stavovima vidimo da se Heidegger zalaže za takvo sveučilište koje će biti najuže povezano s povijesnim subjektom, narodom odnosno njegovom državom i koji svoju samoupravu neće zlorabiti da raskine te veze.

Okretanje početku, neophodno današnjem čovjeku koji je bačen među postojeće u svijetu, znači mogućnost ponovnog postavljanja bitnih pitanja kao najvišeg oblika znanja. Takvo postavljanje pitanja razbit će učahurenost znanosti u zasebna, nepovezana područja i vratiti ih čovjekovom izvornom povijesnom načinu postojanja. Način na koji se ovo mora dogoditi određen je sudbinski, kao borba (Kampf) koja aktivira cijelo čovjekovo tu-biće: »sve voljne i misaone moći, sve snage srca i sve sposobnosti tijela moraju se razviti kroz borbu, jačati $u$ borbi i očuvati kao borba« (GA 16, 116). Pred izvjesnošću sloma duhovne snage Zapada i njegove »prividne« kulture, za Nijemce sve zavisi o tome, misli Heidegger, žele li još uvijek sebe kao »povijesno-duhovni narod « (GA 16, 117). Svoj rektorski govor Heidegger okončava iznoseći uvjerenje da je njemačka omladina o tome već odlučila, prihvaćajući svoj povijesni nalog.

Iako nije ostao imun na zapaljivu retoriku koja je bila važan sustavni moment Hitlerova dolaženja na vlast, što se prepoznaje u izboru termina, postuliranju načela vodstva i preokretanju smisla samouprave u samonametnutu službu, Heideggerov rektorski govor ne može se reducirati na jednostavno zagovaranje nacističke ideologije. U njemu Heidegger zapravo iznosi skicu dalekosežne preobrazbe njemačkog visokog školstva o kojoj intenzivno razmišlja i koju može povezati sa svojim drugim filozofskim mislima. U mjeri u kojoj su se te dvije vizije budućnosti sveučilišta (filozofska i ideološka) poklapale, Heidegger je vjerojatno u nacističkom pokretu vidio socijalnu mogućnost ostvarivanja preobrazbe koju je zamišljao, tog traženog novog početka. Ako je u nekom času povjerovao da bi on mogao iskoristiti pokret za postizanje svojih ciljeva, onda je to izraz njegovog velikog neiskustva, čak naivnosti, u dnevnopolitičkim pitanjima. Vrlo brzo će mu postati jasno da je jedino moguće da pokret iskoristi njega. 
Heideggerov odnos prema nacionalsocijalizmu postaje vrlo složen. U njemu ima gotovo slijepog prihvaćanja, ali ima i jasno izražene oporbe, ne samo unutarnje nego i u čitavom nizu praktičnih situacija s kojima se Heidegger sučeljavao kao rektor. ${ }^{3}$ Iz svega toga on je morao izaći poražen.

U nastojanju da se potvrdi kao vodeći mislitelj pokreta, Heidegger se nije mogao nositi s ljudima efikasnijeg političkog instinkta, pravim naci-filozofima kao što su Rosenberg, Krieck ili Beumler. Njegova je filozofija nepodesna za instrumentaliziranje i skraćivanje kakvo provode ideologije. Moglo bi se reći, Heidegger je bio previše filozof da bi bio dobar nacist.

Ne na posljednjem mjestu, na neuspjeh Heideggerovih težnji ka obnovi sveučilišta utjecala je i unutarnja opozicija konzervativnih akademskih krugova, nesklonih bilo kakvim promjenama, a pogotovu ne onima koje bi ugrozile njihov povlašteni status. Ovi sveučilišni mandarini na koncu su našli modus vivendi u nacističkoj državi i bez većeg protivljenja prihvatili primjenu rasnih zakona (v. Milchman i Rosenberg 1997, 93f).

Kako se sve ovo prelama u tekstu Crnih bilježnica? Mogu li se tu, kada je riječ o sveučilištu, naći novi naglasci, jer u pitanju su zapisi za osobnu uporabu, a u njima njihovi autori obično sebi dopuštaju veći stupanj slobode nego u tekstovima od početka namijenjenim objavljivanju? Potvrdan odgovor na ovo pitanje odnosi se, što je i razumljivo, prije svega na stilizaciju iskaza, ali i na njihov sadržaj.

Upečatljiva je u tom pogledu dijagnoza koju Heidegger iznosi u jednom zapisu nakon razdoblja rektorata. Nakon što za svoj rektorski govor kaže da je bio »mala međuigra jedne velike zablude« (GA 94, 198), ${ }^{4}$ on nastavlja:

»Jer već desetljećima se pripremalo ono što u svom cilju hoće:

Da prirodne znanosti postanu potpuno tehnicizirane.

${ }^{3}$ Dobar pregled djelovanja Heideggera rektora daje Eiland (1986). Možda najuvjerljivija od njegovih gesta oporbe je sprječavanje spaljivanja knjiga »nepoželjnih« autora (uglavnom Židova i ljevičara), što se zbivalo diljem Njemačke, ali je sveučilišna knjižnica u Freiburgu ostala sačuvana. - U jednom zapisu još iz 1934. godine nalazi se ocjena da je nacionalsocijalizam »barbarski princip«, doduše uz uvažavanje i pozitivnih, vitalističkih aspekata barbarstva (GA 94, 194).

${ }^{4}$ Slično: »zabluda ... pred slijepima govoriti o bojama« (GA 94, 258). 
Da duhovne znanosti postanu instrumenti politike i pogleda na svijet.

Da pravna znanost postane izlišna.

Da medicina, i kao biološka, postane tehnika.

Da teologija postane besmislena.« (GA 94, 198-199.)

Tu dijagnozu bi sasvim lako mogao usvojiti i neki današnji kritičar obrazovnog sustava, skupa s pojedinim elementima Heideggerove terminologije, npr. izrazima poluobrazovanje (Halbbildung, koristi ga i Adorno), neobrazovanje i poškolavanje (Unbildung, Verschulung, oba se mogu naći kod Liessmanna). Postoji u Crnim bilježnicama i drugačiji vokabular - primjerice korištenje vojne terminologije u kontekstu kritike sveučilišnog programa: »obrazovati front, postaviti cilj borbe, utvrditi položaj neprijatelja...«(GA 94, 147). Međutim, iz sličnosti misaonih motiva i načina na koji se ti motivi verbalno artikuliraju još ne treba zaključivati o sličnosti kritičkih pozicija.

U citiranom fragmentu jasno možemo izdvojiti najmanje tri važnija momenta. Prvo, smještajući »malu međuigru« svog rektorskog govora i samog rektorata u kontekst jednog dugotrajnog povijesnog procesa, Heidegger ne samo da opravdava neuspjeh koji je doživio nego i želi sebe prikazati kao nekoga tko se (istina, neuspješno) suprotstavio pogrešnom razvitku. Drugo, on kritiku osamostaljenih znanstvenih područja integrira u cjelinu svojega mišljenja, naglašavajući tehnički karakter njihova osamostaljivanja, što time potpada pod njegovu kritiku tehničko-spravljujuće racionalnosti Novoga vijeka. I treće, on rezultat tog razvojnog procesa dosljedno prikazuje kao pervertiranje izvornog smisla znanosti, s filozofijom kao svojim izvorom i središtem. Uzeta kao cjelina, ova dijagnoza implicira potrebu da se pogrešan razvitak zaustavi i preokrene. Ali kako to učiniti, kojim sredstvima? Ovo pitanje markira jednu od najvažnijih specifičnosti Heideggerova shvaćanja sveučilišta.

Namjesto univerzalnog prosvjetiteljskog odgovora, primjerice $u$ obliku kakav mu je dao Kant formulom o hrabrosti za korištenje vlastitoga razuma, Heidegger odgovara sukladno svome skučenom narodnjaštvu koje se maskira u filozofski iskaz. »Ako sveučilište i nadalje treba pripadati našem narodu«, kaže on, »onda se njegov nalog za odgoj znanja (Wissenerziehung) mora posve drugačije izvorno ukorijeniti (...) iz nužde za znanjem kao jednog osnovnog vida bića našeg naro- 
da«. ${ }^{5}$ Pri tome, cilj nije znanstveni napredak po sebi, nego »učenje kao odgoj« (GA 94, 123). Na drugom mjestu, sam ovaj odgoj određen je kao »budilačko i spajajuće provođenje državne moći kao volje jednog naroda za sebe samog« (GA 94, 121). Štoviše, Heidegger se izrijekom distancira od prosvjetiteljske pozicije tvrdnjom da počinje doba u kojemu se moramo ponovno vezivati za izvorne moći predanja, a ne upuštati se u oslobađajuće oblikovanje, što je odlika prosvjećenosti (GA 94, 126). Odbojan stav prema (prosvjetiteljskoj) kulturi pokazuje se i na drugim mjestima u Crnim bilježnicama, karakteristično u jednom zapisu u kojemu Heidegger izlaže smisao »odgoja znanja«:

»Ne potvrđivati svoj znanstveni ugled na međunarodnim kongresima, nego buditi bitnu snagu postojanja našeg naroda - ne podticati našu 'kulturu', nego izboriti jasnoću volje za postojanjem...« (GA 94, 144)

Heideggerova volja za obnovom izvornog bića sveučilišta bila je neostvarena i zato je za njega »bitno iskustvo« godine rektorata uvid $\mathrm{u}$ »nezaustavljivi kraj sveučilišta u svakom smislu« i to uslijed »nemoći za pravo samopotvrđivanje« (GA 94, 154). Zato je, po njemu, sveučilište "preko noći« (kako se to odnosi prema onim desetljećima iz ranije citiranog fragmenta?) izgubilo utjecaj i položaj »u javnom životu naroda« i sada mu preostaje samo jedno »antikvarno« postojanje i uloga ustanove koja što je moguće brže snabdijeva studente »građom znanja« potrebnom za obavljanje poziva (GA 94, 161). Na djelu je sve obuhvatnije »poškolavanje« sveučilišta, ono neumitno postaje »stručna škola« (GA 94, 193).

Po okončanju »male međuigre« čiji posljednji dan (28. travanj 1934.) i njegovu atmosferu u Crnim bilježnicama markira zajedljiva notica: »Neka žive mediokritetstvo i galama!« (GA 94, 161), Heidegger se sve rjeđe upušta u razmatranje teme sveučilišta. U jednom zapisu iz 1938. on se ponovno osvrće na svoj rektorat i rektorski govor. Sada "grešku« svog govora vidi u tome što »prekoračuje zakonitosti bîti današnje znanosti«, kao i u htjenju da ponovno dođe do »znanosti« iako

${ }^{5}$ Heidegger može osnažiti svoju poziciju ovakvim argumentiranjem: shvaćene kao tehnike, znanosti su nužno internacionalne; ali »ne postoji internacionalno mišljenje, nego samo univerzalno mišljenje koje izvire iz nekog pojedinca«; a ovaj, sa svoje strane, da bi mogao ostati blizu izvora nužno je upućen na »stanovanje u jednoj jedinoj domovini i jedinom narodu«; i samo takva ukorijenjenost čuva rast u ono univerzalno (GA 97, 59-60). 
je u Novome vijeku znanost došla do svoga konca. Ma koliko radikalni, pokušaji obnove sami po sebi nisu dovoljni, jer »puka revolucija u postojećem bez preobražaja bića neće stvoriti izvornu povijest, nego samo učvrstiti postojeće« $(\mathrm{GA} 95,18)$. Ono što je (bilo) potrebno Heidegger formulira kao bitnu odluku, odnosno »odluku o biti i određenju Nijemaca a time i sudbine Zapada«. Za Heideggera, sama filozofija ima karakter odlučivanja, pri tome ona ne odlučuje bilo kako o bilo čemu, nego »razvija bitne odluke o onome što je bitno odlučivo« (GA 95, $125){ }^{6}$

Tema sveučilišta ponovno se češće pojavljuje u Heideggerovim zapisima koncem 1945. kada je, u sklopu denacifikacije Njemačke, odstranjen iz nastave. S obzirom na opće okolnosti, intonacija tih zapisa je neobična: Heidegger je zaokupljen obratom u svojoj sudbini i kao da ne primjećuje užasna razaranja koja je donio rat, a kada ih i vidi, nastoji ih objasniti nekim osobitim, transhistorijskim razlozima. ${ }^{7}$ On je sada osobno pogođen i povrijeđen, a stupanj osjećaja povrijeđenosti i nepravde koja ga je zadesila ide sve do iskaza kao što je onaj da njegovo »izbacivanje« iz sveučilišne nastave graniči s »nečim najgorim što je Nijemac priredio drugom Nijemcu« (GA 97, 79-80). Reći tako nešto neposredno po okončanju rata tijekom kojega je Nijemac itekako mnogo toga, pa i onog najgoreg, priređivao drugome, pogotovo ne-Nijemcu, graniči s najtežim oblikom moralnog sljepila. Ako je bio previše filozof da bi bio dobar nacist, ovdje se, suočen s vlastitim ljudskim, odviše ljudskim, Heidegger pokazuje kao nedovoljno filozof.

Zabrana nastavne djelatnosti Heideggeru je osobito teško pala jer predavanja za njega nisu bila školska obveza, nego djelatnost u koju se unosio čitavim svojim tu-bićem, jer je bio, kako sam kaže, »strastven učitelj« (GA 97, 57). Uostalom, ta strast s kojom je pred svojim slušateljima ponovno postavljao osnovno pitanje o biću bila je osnovni činitelj njegove iznimne privlačnosti među studentima i doktorandima filozofije u Njemačkoj već od ranih dvadesetih godina. Lista njihovih

${ }^{6}$ U ožujku 1946. on »pravu zabludu« razdoblja rektorata vidi u tome što je mislio da je došlo vrijeme da se bavi ne Hitlerom, kao »drugi, pametniji«, nego »buđenjem naroda u njegovoj zapadnjačkoj sudbini« (GA 97, 98).

${ }^{7}$ Za njega se pravi poraz ne sastoji u raspadu »Reicha«, razaranju gradova i masovnim pogibijama, nego u tome što su se Nijemci upustili u »samouništenje svoje biti« (GA 97, 156). 
imena (a među njima veliki broj židovskih) djeluje kao Tko je tko u njemačkoj filozofiji u drugoj polovici dvadesetog stoljeća. Zanimljivo je da u nastavku ovog zapisa Heidegger, imajući svjesno ili ne pred očima Platonovo davanje prednosti živom logosu pred zapisanim logosom, izlaže argument o nadmoćnosti govora u usporedbi s tekstom.

Kritika sveučilišta u godinama nakon »razrješenja« postaje oštrija i otvorenija, pokatkad čak i gruba. Sveučilištu (podrazumijeva se: njemačkom) »više nije potrebno mišljenje « (GA 97, 36), ono u sebi ne posjeduje potencijal za "pozitivnu kritiku«, već se sve pretvara u »jurnjavu za uspjehom« u kojoj pojedinačna sveučilišta konkuriraju jedna drugima »kao banjska mjesta « (GA 97, 164). Sveučilište je »političko-crkveni« instrument (GA 97, 388); ono služi - ali ne »istini«, nego znanostima i njihovom napretku. Znanosti kao »sredstva tehnike« danas su potrebnije nego ikada, a svoju tehničku funkciju one će ispuniti još bolje i čistije ako se oslobode ostataka filozofije u sebi (GA 97, 388-389). Osobito u ovim gorko-oštrim ocjenama stvarnosti sveučilišta zapaža se možda i neočekivana sličnost sa stanjem sveučilišta početkom dvadeset i prvog stoljeća!

Ništa bolje ne stoji niti s filozofijom na sveučilištima. Njoj prijeti da postane stvar struke ili poziva, bez dodira s izvornim filozofskim pitanjima. »Baviti se« filozofijom još ne znači filozofski misliti. Netko takav će onda »glasnije od drugih govoriti o filozofiji« i gurati se na scenu njenom upotrebom jezika. »Takvo polovično mišljenje«, upozorava Heidegger, »opasnije je od nemanja misli« (GA 97, 187). Beskrajno prilagodljivo, polovično mišljenje ovladalo je atmosferom sveučilišne nastave filozofije.

U nastojanju da se iz ovog pregleda prisustva teme sveučilišta u Heideggerovim Crnim bilježnicama izvedu neki zaključci, nameću se sljedeći interpretativni stavovi:

1. U svojoj filozofskoj osnovi i po sadržaju Heideggerovi zapisi o sveučilištu u suglasju su s drugim njegovim idejama, pogotovu onima izloženima u rektorskom govoru o Samopotvrđivanju njemačkog sveučilišta. Te ideje po svom su karakteru anti-prosvjetiteljske i anti-moderne, ali ne i konzervativne; to je jedan od razloga Heideggerova angažmana oko radikalnosti nacionalsocijalizma.

2. I pored zapaljivog vokabulara kojim su neki put izražene, te se ideje ne podudaraju sa sadržajima nacističke ideologije, već su elementi 
Heideggerove vizije o korjenitoj preobrazbi sveučilišta, znanosti i znanja.

3. Mogu se jasno razlikovati tri faze u Heideggerovom mišljenju o sveučilištu u Crnim bilježnicama (uz podrazumijevane aspekte koji se ne mijenjaju); te tri faze određene su okolnostima koje pripadaju misliteljevoj biografiji. Konkretno, prva faza počinje zapisima iz prve polovice 1933., neposredno prije Heideggerova preuzimanja rektorata, i njom dominiraju ideje o bîti sveučilišta i projekcije njegove obnove. Druga faza počinje pred napuštanje pozicije rektora u proljeće 1934., izrazito je kritički obojena, sadrži elemente Heideggerova samopropitivanja i ovdje-ondje nalazi odjeke i u zapisima nastalima godinama kasnije. U trećoj fazi, koja počinje u prosincu 1945. nakon što je saznao da će biti razriješen nastave, Heidegger kritici sveučilišta dodaje obranu vlastitog iskustva predavanja. Po povratku u nastavu 1948., tema sveučilišta upadljivo izostaje iz Heideggerovih zapisa. Naravno, ovo posljednje zapažanje limitirano je činjenicom da još uvijek nisu objavljene sve Crne bilježnice.

\section{Literatura}

Heidegger, Martin, Gesamtausgabe,

- Band 16 (2000), Reden und andere Zeugnisse eines Lebensweges, hrsg. Heidegger, Hermann;

- Band 94 (2014), Überlegungen II-VI (Schwarze Hefte 1931-1938);

- Band 95 (2014), Überlegungen VII-XI (Schwarze Hefte 1938/39);

- Band 96 (2014), Überlegungen XII-XV (Schwarze Hefte 1939-1941);

- Band 97 (2015), Anmerkungen I-V (Schwarze Hefte 1942-1948);

- Band 98 (2018), Anmerkungen VI-IX (Schwarze Hefte 1948/49-1951); hrsg. Trawny, Peter; Frankfurt am Main: Vittorio Klostermann.

Eiland, Howard (1986), »Heidegger's political engagement«, Salmagundi, 70-71, str. 267-284.

Grondin, Jean (2016), »Warum ich Heidegger in schwieriger Zeit treu bleibe«, in: Homolka, Walter i Heidegger, Arnulf (hrsg.), Heidegger und Antisemitismus. Positionen im Widerstreit, Freiburg/München: Herder Verlag, str. 232-241.

von Herrmann, Friedrich-Wilhelm (2016), »The role of Martin Heidegger's Notebooks within the context of his oeuvre«, in: Farin, Ingo i Malpas, Jeff (ur.), Reading Heidegger's Black Notebooks 1931-1941, Cambridge, MA: The MIT Press, str. 89-94. 
von Herrmann, Friedrich-Wilhelm i Alfieri, Francesco (2017), Martin Heidegger. Die Wahrheit über die Schwarzen Hefte, Berlin: Duncker \& Humblot.

Milchman, Alan i Rosenberg, Alan (1997), »Martin Heidegger and the university as a site for the transformation of human existence«, The Review of Politics, 59(1), str. 75-96.

Puzić, Maik i Pégny, Gaëtan (2017), »Bibliographie zu den Schwarzen Heften«. Dostupno na: https://www.uni-siegen.de/phil/philosophie/tagung/bibliographie zu den schwarzen heften.pdf [9. 4. 2020.]

Serafin, Andrzej (2015), »A reception history of the Black Notebooks«, Gatherings: The Heidegger Circle Annual, 5, str. 118-142.

\section{TOPIC OF UNIVERSITY IN MARTIN HEIDEGGER'S $B L A C K$ NOTEBOOKS}

\section{Saša Radojčić}

The notes that Martin Heidegger made in the so-called Black Notebooks stimulated, immediately after publication, intense discussions, especially on the issue of anti-Semitism and National Socialism. Does Heidegger's personal fondness for these ideologies reflect on his philosophical work? In this essay, one important topic related to these issues in Black Notebooks is discussed - the topic of university. It became more frequent on three occasions, marked by significant events in Heidegger's professional biography: taking over as rector of the University of Freiburg (1933), leaving that position (1934), and exclusion from teaching as part of the postwar denazification of Germany (1945). It turns out that the understanding of the university in the Black Notebooks corresponds to the ideas presented in Heidegger's rector's speech, and that this understanding is not equally National Socialist, but expresses the philosopher's "populist" thinking. Although he possesses some elements of vocabulary that were present in Nazi propaganda, Heidegger integrates his views on the reality and future of the university with his other ideas - a critique of reducing knowledge to technical aspects, a critique of isolating science into independent fields, and a critique of Western thought.

Key words: Martin Heidegger, university, National Socialism, science, critique of technology 